\title{
Caffeic Acid Induced Apoptosis in MG63 Osteosarcoma Cells Through Activation of Caspases
}

\author{
Ferry Sandra ${ }^{1,2}$, Meta Ariyani Sidharta ${ }^{3}$ \\ ${ }^{1}$ Department of Biochemistry and Molecular Biology, Division of Oral Biology, Faculty of Dentistry, Trisakti University, Jakarta, \\ Indonesia \\ ${ }^{2}$ Doctoral Program in Medical Science, Faculty of Medicine, University of Sumatera Utara, Medan, Indonesia \\ ${ }^{3}$ Faculty of Dentistry, Trisakti University, Jl. Kyai Tapa No.260, Jakarta, Indonesia
}

Background: Caffeic acid has been reported that when it is combined with all-trans retinoic acid, it can inhibit proliferation activity of SaOS-2 or OSA-01 cells. In addition, caffeic acid merely could reduce cell viability of SaOS-2 cells. However, there is not any study in caffeic acid's possible effect to induce apoptosis in osteosarcoma cell.

Materials and Methods: MG-63 cells were cultured in Dulbecco's Modified Eagle Medium containing 10\% fetal bovine serum. Cells were treated with various concentrations of caffeic acid. Apoptosis were analyzed with Sub-G1 assay and activation of caspase-8, -9 , and -3 were analyzed with immunoblotting. Caffeic acid-induced percentage of apoptotic cells and cleaved-8, $-9,-3$ were then statistically analyzed.

Results: Sub-G1 results showed that caffeic acid significantly induced apoptosis in MG-63 osteosarcoma cells in concentration dependent manner. Immunoblotting results showed that caffeic acid induced cleavage of caspase-8, -9 and -3 . Cleavedcaspase- 8 and -9 were increased at 1-hour treatment of caffeic acid, while cleaved-caspase 3 was increased markedly at 6-hours treatment of caffeic acid.

Conclusion: Caffeic acid induces apoptosis significantly in concentration dependent manner through caspase-dependent intrinsic apoptotic pathway.

Keywords: caffeic acid, osteosarcoma, MG-63, apoptosis, caspase

\section{Introduction}

Osteosarcoma is the most common primary malignant bone tumor in children and adolescents. Osteosarcoma originates from primitive mesenchymal bone forming cells and often occurs in long bones, such as proximal tibia and distal femur. ${ }^{1,2}$ Osteosarcoma was rarely curable even with treatment of ablative surgery. ${ }^{2}$ Some clinical studies reported regime consists of the combination of surgery and intensive

Date of submission: June 8,2016

Last Revised: August 25, 2016

Accepted for publication: August 30, 2016

\footnotetext{
Corresponding Author:

Ferry Sandra

Department of Biochemistry and Molecular Biology, Division of Oral Biology

Faculty of Dentistry, Trisakti University, Jl. Kyai Tapa No.260

Jakarta, Indonesia

E-mail: ferrysandra@gmail.com
}

multi-agent chemotherapy improved currently 5-year overall survival rate to $60-80 \% 0^{1,2}$ However poor response to treatment regimes is still remained. ${ }^{1}$ Therefore novel approach is still underway to provide better response ${ }^{1}$ and to limit the use of various combination of chemotherapies due to possible side effects. ${ }^{3}$

Nowadays several new therapeutic agents, which specifically target proliferation, cell angiogenesis, immune 
system signaling pathways in cancer cells, either as single therapeutic agent or in combination with conventional chemotherapy, have showed promising data in preclinical research and clinical trials. ${ }^{1}$ In addition approach in inducing apoptosis in osteosarcoma cells was also being introduced. ${ }^{4}$ Ursolic acid, ${ }^{5}$ ferulic acid, polydatin, ${ }^{6}$ mistletoe alkali ${ }^{7}$ and many others, trigger apoptosis in human MG-63 osteosarcoma cells.

Caffeic acid (3,4-dihydroxycinnamic acids), a natural resource, occurs in food mainly as an ester with quinic acid called chlorogenic acid (3-O-caffeoylquinic acid). ${ }^{8}$ Caffeic acid has been well reported to inhibit osteoclastogenesis. ${ }^{8-10}$ Besides osteoclastogenesis, caffeic acid was reported to induce apoptosis in SCM1 gastric and HeLa cervical cancer cells. ${ }^{11,12}$ Caffeic acid has been reported that when it is combined with all-trans retinoic acid, the inhibitory effect in proliferation activity of SaOS-2 or OSA-01 cells was significantly increased. ${ }^{13}$ In addition, caffeic acid merely could reduce cell viability to around $55 \%$ in SaOS-2 cells. 13 However, to our knowledge, there is not any study in caffeic acid's possible effect to induce apoptosis in osteosarcoma cell. Therefore current study was conducted to investigate the apoptotic effect of caffeic acid in osteosarcoma cells.

\section{Materials and methods}

\section{Cell culture}

MG-63 cells were cultured in Dulbecco's Modified Eagle Medium (Gibco, Grand Island, NY, USA), containing 10\% fetal bovine serum (Gibco) and antibiotic-antimycotic containing 200 units $/ \mathrm{mL}$ penicillin, $200 \mu \mathrm{g} / \mathrm{mL}$ streptomycin and $0.5 \mu \mathrm{g} / \mathrm{mL}$ amphotericin (Gibco) in a humidified, $37^{\circ} \mathrm{C}$, $5 \% \mathrm{CO} 2$ incubator. Upon reaching $80 \%$ confluence, cells were sub-cultured.

\section{Sub-G1 assay}

Sub-G1 assay of apoptotic cells was performed as described by Sandra et al. ${ }^{14,15}$ Briefly, MG63 cells were treated with 0-10 $\mu \mathrm{g} / \mathrm{ml}$ caffeic acid (Wako, Osaka, Japan) or chlorogenic acid (Wako, Osaka, Japan), harvested and suspended in $1 \mathrm{~mL}$ of hypotonic fluorochrome solution $(50 \mu \mathrm{g} / \mathrm{mL}$ propidium iodide in $0.1 \%$ sodium citrate plus $0.1 \%$ Triton $\mathrm{X}-100$ ). Cell suspension was placed at $4{ }^{\circ} \mathrm{C}$ in the dark for 2 hours before the flow cytometric analysis. The propidium iodide fluorescence of individual nuclei was measured with a FACSCanto II flow cytometer (Becton Dickinson, Franklin Lakes, NJ, USA).

\section{Immunoblotting}

Stimulated cells were harvested and incubated with lysis buffer containing $20 \mathrm{mM}$ Tris buffer ( $\mathrm{pH} 7.4$ ), $5 \mathrm{mM}$ EDTA, $1 \%$ Triton-X, $50 \mathrm{mM}$ sodium fluoride, $2 \mathrm{mM}$ sodium orthovanadate, $10 \mathrm{mM}$ sodium pyrophosphate, $1 \mathrm{mM}$ p-amidinophenyl methanesulfonyl fluoride hydrochloride and protease inhibitor cocktail (Sigma, St. Louis, MO, USA). Samples were separated by sodium dodecyl sulfate (SDS)-polyacrylamide gel electrophoresis and transferred to a pure nitrocellulose membrane. After blocking with 5\% skim milk in phosphate buffer saline (pH 7.4), the sheets were probed with the following 1:1000 diluted antibodies: mouse monoclonal anti-cleaved caspase-8 (Asp384) (Cell Signaling, Beverly, MA, USA), rabbit polyclonal anti-cleaved caspase-9 (Asp315) (Cell Signaling) and rabbit polyclonal anti-cleaved caspase-3 (Asp175) (Cell Signaling). The secondary antibody was 1:1000 diluted horseradish peroxidase (HRP)-conjugated donkey antirabbit (Amersham, Buckinghamshire, UK) or 1:2000 diluted horseradish peroxidase-conjugated sheep antimouse (Amersham) antibody. The bound antibodies were visualized using Immun Star HRP Chemiluminescent Kit (BioRad, Hercules, CA, USA). All visualized bands were captured using Alliance 4.7 (UVItech, Cambridge, UK) and semi-quantified using UVIband software (UVItech).

\section{Statistical analysis}

Shapiro Wilk test was performed to detemine distribution of apoptosis induced by caffeic acid or chlorogenic acid in various concentrations with Sub-G1 assay, and $10 \mu \mathrm{g} /$ $\mathrm{mL}$ caffeic acid-induced cleaved-caspase- $8,-9$ or -3 in serial time with immunoblotting. Independent samples $\mathrm{T}$ or Mann Whitney test was perfomed to compare apoptosis induced by caffeic acid and chlorogenic acid in various concentrations with Sub-G1 assay and $10 \mu \mathrm{g} / \mathrm{mL}$ caffeic acid-induced cleaved-caspase- $8,-9$ and -3 in serial time with immunoblotting. Statistical analyses were performed using IBM SPSS Statistics for Macintosh version 21 (SPSS IBM, Armonk, NY, USA). Statistically significance was expressed as $p<0.05$.

\section{Results}

Caffeic acid induced apoptosis in MG-63 cells significantly MG-63 cells were significantly induced into apoptosis by treatment of caffeic acid (Figure 1A, Table 1 and 3). Results showed that $0,0.1,1$ and $10 \mu \mathrm{g} / \mathrm{mL}$ caffeic acid induced 23.00 
$\pm 1.00 \%, 35.67 \pm 3.06 \%, 43.67 \pm 3.79 \%, 81.00 \pm 3.61 \%$ of apoptotic cells, respectively (average \pm standard deviation). Percentages of apoptotic cells were significantly increased along with the increment of caffeic acid concentrations. Meanwhile, chlorogenic acid concentration-dependently induced apoptosis in MG-63 cells as well (Figure 1B), but resulted percentages of apoptotic cells were markedly lower.
Chlorogenic acid in concentration of $0,0.1,1$ and $10 \mu \mathrm{g} /$ $\mathrm{mL}$ induced $23.00 \pm 1.00 \%, 26.33 \pm 2.52 \%, 31.00 \pm 3.46 \%$, $36.67 \pm 3.51 \%$ of apoptotic cells, respectively.

Caffeic acid induced apoptosis through caspase-8, -9 and $-3$

Based on immunoblotting results (Figure 2A, Table 2 and 4), all cleaved-caspase- $8,-9$ and -3 were observed. Bands

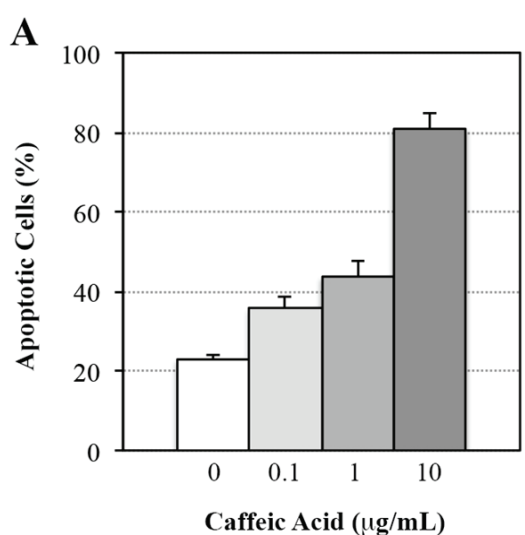

A

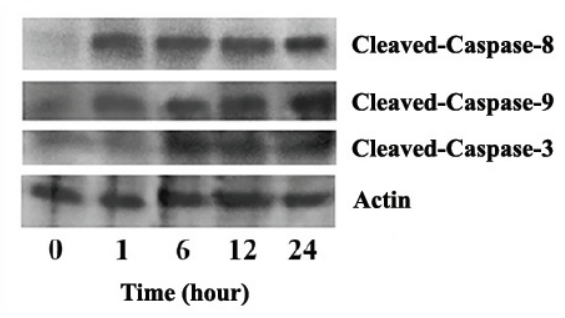

C

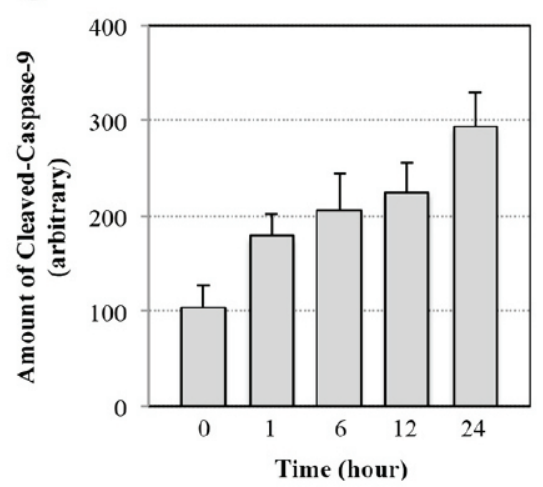

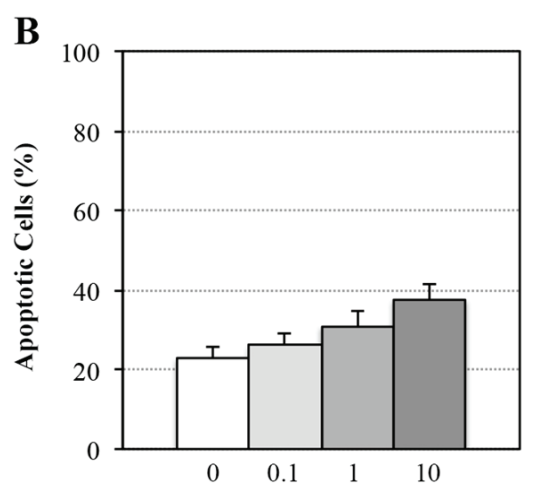

Chlorogenic Acid ( $\mu \mathrm{g} / \mathrm{mL})$

B

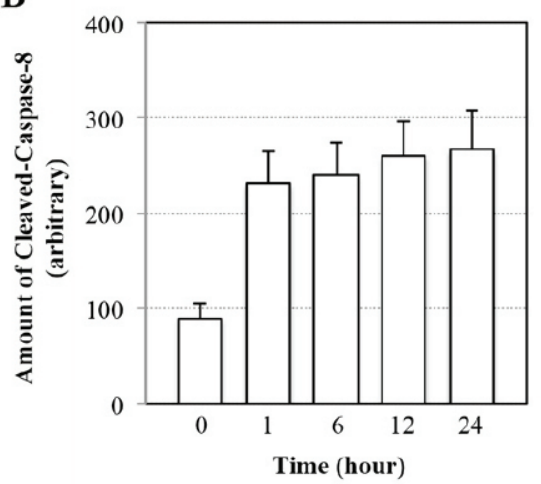

D

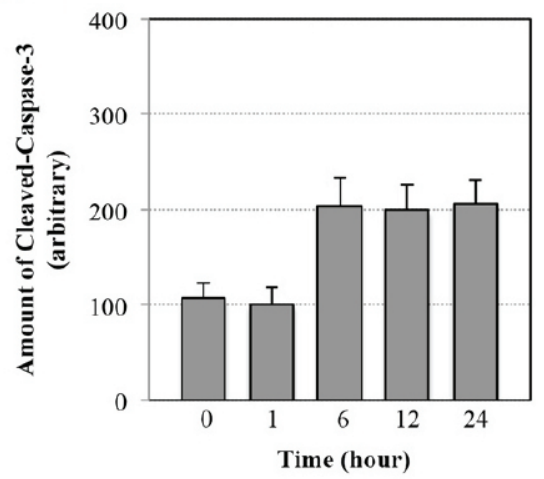

Figure 1. Caffeic acid induced apoptosis in MG-63 cells. MG-63 cells were starved for 12 hours and treated with various concentrations of caffeic acid (A) or chlorogenic acid (B) for 48 hours. Cells were collected and processed according to Sub-G1 assay. These experiments were repeated 3 times.
Figure 2. Caffeic acid induced cleavages of Caspase-8, -9 and $\mathbf{- 3}$. MG-63 cells were starved for $12 \mathrm{hr}$ and treated with $10 \mu \mathrm{g} / \mathrm{mL}$ caffeic acid for $0,1,6,12$ and 24 hours. Cells were collected, lysed and processed further for immunoblotting to detect cleaved caspase- $8,-9$ and -3 . These experiments were repeated 3 times. 
of cleaved-caspase- 8 were increased markedly started from treatment of caffeic acid for 1 hour and increased slightly until 24 hours. Semi-quantification of caspase-8 (Figure 2B) confirmed the results and showed the cleavages were significantly induced by caffeic acid at 1-hour treatment. Bands of cleaved-caspase 9 were seen started from treatment of caffeic acid for 1 hour, then gradually increased. Semiquantification of caspase-9 (Figure 2C) showed significant time-dependent of cleaved-caspase 9 formations. Bands of cleaved-caspase 3 were increased markedly started from treatment of caffeic acid for 6 hours and maintained constant until 24 hours. Semi-quantification of caspase-3 (Figure 2D) confirmed the results and showed the cleavages were significantly induced by caffeic acid at 6 hours treatment.

\section{Discussion}

Our investigation in caffeic acid was initially started from its potential in inhibiting RANKL and TNFinduced osteclastogenesis. ${ }^{8-10}$ Several reports showed that tumor cells could induce osteoclastogenesis, including ameloblastoma $^{16}$, oral cancer $^{17}$ and osteosarcoma ${ }^{18} /$

Table 1. Comparative statistical analysis of apoptosis induced by caffeic acid or chlorogenic acid in various concentrations with Sub-G1 assay.

\begin{tabular}{ccccc}
\hline \multicolumn{1}{c}{ Group } & $\begin{array}{c}\text { One Way } \\
\text { Analysis }\end{array}$ & \multicolumn{3}{c}{ Comparative Analysis } \\
\hline Caffeic Acid & & $0.1 \mu \mathrm{g} / \mathrm{mL}$ & $1 \mu \mathrm{g} / \mathrm{mL}$ & $10 \mu \mathrm{g} / \mathrm{mL}$ \\
\hline $0 \mu \mathrm{g} / \mathrm{mL}$ & ANOVA & $0.002^{\mathrm{a}, *}$ & $0.001^{\mathrm{a}, *}$ & $0.000^{\mathrm{a}, *}$ \\
$0.1 \mu \mathrm{g} / \mathrm{mL}$ & $\mathrm{p}=0.000^{*}$ & - & $0.046^{\mathrm{a}, *}$ & $0.000^{\mathrm{a}, *}$ \\
$1 \mu \mathrm{g} / \mathrm{mL}$ & & $0.046^{\mathrm{a}, *}$ & - & $0.000^{\mathrm{a}, *}$ \\
\hline Chlorogenic Acid & & $0.1 \mu \mathrm{g} / \mathrm{mL}$ & $1 \mu \mathrm{g} / \mathrm{mL}$ & $10 \mu \mathrm{g} / \mathrm{mL}$ \\
\hline $0 \mu \mathrm{g} / \mathrm{mL}$ & & $0.100^{\mathrm{a}}$ & $0.046^{\mathrm{b}, *}$ & $0.002^{\mathrm{a}, *}$ \\
$0.1 \mu \mathrm{g} / \mathrm{mL}$ & Kruskal Wallis & - & $0.077^{\mathrm{b}}$ & $0.010^{\mathrm{a}, *}$ \\
$1 \mu \mathrm{g} / \mathrm{mL}$ & $\mathrm{p}=0.024^{*}$ & $0.077^{\mathrm{b}}$ & - & $0.121^{\mathrm{a}}$ \\
\hline
\end{tabular}

andependent samples T test, ${ }^{\mathrm{b}}$ Mann Whitney, ${ }^{*} p<0.05$.

Table 2. Comparative statistical analysis of $10 \mu \mathrm{g} / \mathrm{mL}$ caffeic acid-induced cleavedcaspase-8, -9 or $\mathbf{- 3}$ in different time with immunoblotting.

\begin{tabular}{|c|c|c|c|c|c|}
\hline Group & $\begin{array}{c}\text { One Way } \\
\text { Analysis }\end{array}$ & & Compara & e Analysis & \\
\hline Cleaved-Caspase 8 & & 1 hour & 6 hour & 12 hours & 24 hours \\
\hline 0 hour & & $0.003^{\mathrm{a}, *}$ & $0.046^{\mathrm{b}, *}$ & $0.002^{\mathrm{a}, *}$ & $0.002^{\mathrm{a}, *}$ \\
\hline 1 hour & Kruskal Wallis & - & $0.268^{\mathrm{b}}$ & $0.374^{\mathrm{a}}$ & $0.321^{\mathrm{a}}$ \\
\hline 6 hours & $\mathrm{p}=0.071$ & $0.268^{\mathrm{b}}$ & - & $0.268^{\mathrm{b}}$ & $0.268^{\mathrm{b}}$ \\
\hline 12 hours & & $0.374^{\mathrm{a}}$ & $0.268^{\mathrm{b}}$ & - & $0.845^{\mathrm{a}}$ \\
\hline Cleaved-Caspase 9 & & 1 hour & 6 hour & 12 hours & 24 hours \\
\hline 0 hour & & $0.063^{\mathrm{a}}$ & $0.016^{\mathrm{a}, *}$ & $0.005^{\mathrm{a}, *}$ & $0.002^{\mathrm{a}, *}$ \\
\hline 1 hour & ANOVA & - & $0.450^{\mathrm{a}}$ & $0.210^{\mathrm{a}}$ & $0.026^{\mathrm{a}, *}$ \\
\hline 6 hours & $\mathrm{p}=0.001^{*}$ & $0.450^{\mathrm{a}}$ & - & $0.549^{\mathrm{a}}$ & $0.046^{\mathrm{a}, *}$ \\
\hline 12 hours & & $0.002^{\mathrm{a}, *}$ & $0.549^{\mathrm{a}}$ & - & $0.066^{\mathrm{a}}$ \\
\hline Cleaved-Caspase 3 & & 1 hour & 6 hour & 12 hours & 24 hours \\
\hline 0 hour & & $0.649^{\mathrm{a}}$ & $0.006^{\mathrm{a}, *}$ & $0.007^{\mathrm{a}, *}$ & $0.004^{\mathrm{a}, *}$ \\
\hline 1 hour & ANOVA & - & $0.006^{\mathrm{a}, *}$ & $0.007^{\mathrm{a}, *}$ & $0.004^{\mathrm{a}, *}$ \\
\hline 6 hours & $\mathrm{p}=0.000^{*}$ & $0.006^{\mathrm{a}, *}$ & - & $0.794^{\mathrm{a}}$ & $0.942^{\mathrm{a}}$ \\
\hline 12 hours & & $0.004^{\mathrm{a}, *}$ & $0.794^{\mathrm{a}}$ & - & $0.728^{\mathrm{a}}$ \\
\hline
\end{tabular}

andependent samples T test, ${ }^{\mathrm{b}}$ Mann Whitney, ${ }^{*} p<0.05$. 
Table 3. Distribution analysis of apoptosis induced by caffeic acid or chlorogenic acid in various concentrations with Sub-G1 assay.

\begin{tabular}{ccc}
\hline \multicolumn{1}{c}{ Group } & Shapiro-Wilk & Distribution \\
\hline Caffeic Acid & & \\
\hline $0 \mu \mathrm{g} / \mathrm{mL}$ & 1.000 & normal \\
$0.1 \mu \mathrm{g} / \mathrm{mL}$ & 0.637 & normal \\
$1 \mu \mathrm{g} / \mathrm{mL}$ & 0.253 & normal \\
$10 \mu \mathrm{g} / \mathrm{mL}$ & 0.537 & normal \\
\hline Chlorogenic Acid & & \\
\hline $0 \mu \mathrm{g} / \mathrm{mL}$ & 1.000 & normal \\
$0.1 \mu \mathrm{g} / \mathrm{mL}$ & 0.780 & normal \\
$1 \mu \mathrm{g} / \mathrm{mL}$ & 0.000 & abnormal \\
$10 \mu \mathrm{g} / \mathrm{mL}$ & 0.843 & normal \\
\hline
\end{tabular}

Table 4. Distribution analysis of $10 \mu \mathrm{g} / \mathrm{mL}$ caffeic acid-induced cleaved-caspase-8, -9 or -3 in different time with immunoblotting.

\begin{tabular}{lcc}
\hline \multicolumn{1}{c}{ Group } & Shapiro-Wilk & Distribution \\
\hline Cleaved-Caspase 8 & & \\
\hline 0 hour & 0.058 & normal \\
1 hour & 0.144 & normal \\
6 hours & 0.000 & abnormal \\
12 hours & 0.537 & normal \\
24 hours & 0.114 & normal \\
\hline Cleaved-Caspase 9 & & \\
\hline 0 hour & 0.497 & normal \\
1 hour & 0.107 & normal \\
6 hours & 0.253 & normal \\
12 hours & 0.157 & normal \\
24 hours & 0.132 & normal \\
\hline Cleaved-Caspase 3 & & \\
\hline 0 hour & 0.637 & normal \\
1 hour & 0.148 & normal \\
6 hours & 0.702 & normal \\
12 hours & 0.416 & normal \\
24 hours & 0.194 & normal \\
\hline
\end{tabular}

Ewing sarcoma ${ }^{19}$ cells. Later on, caffeic acid with/without combination of retinoic acid was found out to inhibit proliferation of osteosarcoma cells. ${ }^{13}$ Current results added more information that caffeic acid could induce apoptosis in osteosarcoma cells significantly and specifically, apoptosis induced by chlorogenic acid was much lower than caffeic acid. The apoptotic induction potential of caffeic acid has been reported in different cancer cells, SCM1 gastric and HeLa cervical cancer cells as well. ${ }^{11,12}$ In addition, current results showed percentages of apoptotic cells were significantly increased along with the increment of caffeic acid concentrations, suggesting that caffeic acid induced apoptosis in MG-63 cells in a concentration dependent manner.

Current results showed that caffeic acid induced apoptosis through caspase- $8,-9$ and -3 , suggesting that mitochondrial or intrinsic apoptotic signaling pathway could also be involved. These results are in accordance to previous report, caffeic acid induced translocation of cytochrome $\mathrm{c}$ from mitochondria to cytoplasm in HeLa cells. ${ }^{12}$ Caspase activation has been recognized as the key to apoptosis, in which the presence of caspase which has been cleaved or activated marking the cells undergo apoptosis. ${ }^{20}$ Apoptosis involves diverse cell proteases and response to various apoptotic signals. Cleavage and degradation of the protease would result in cell death. Cleaved-caspase 3 was reported to push the cell into apoptosis and the action was irreversible. Thus, caspase 3 is an apoptotic executor, which is an important target for regulating apoptosis. ${ }^{21}$

Caspase- 8 and -9 are essential proteases for intrinsic apoptotic pathways, which caspase-3 will act as a downstream effector in the pathway. ${ }^{22,23}$ Although the intrinsic and extrinsic pathways involve some different molecules, but both of these pathways can be interconnected. ${ }^{23}$ Activation of caspase- 8 can directly lead to the activation of extrinsic pathway and/or activation of Bid, which then will affect mitochondrial membrane potential and cytochrome c release will be initiated. Taken together, current results suggested that caffeic acid induces apoptosis significantly in concentration dependent manner through caspase-dependent intrinsic apoptotic pathway. Further investigation on extrinsic apoptotic pathway should be conducted.

\section{Acknowledgements}

Authors are thankful to Dr. Masanobu Ohishi for technical supports.

\section{References}

1. Shaikh AB, Li F, Li M, He B, He X, Chen G, et al. Present Advances and Future Perspectives of Molecular Targeted Therapy for Osteosarcoma. Int J Mol Sci. 2016; 17(4): 506. doi: 10.3390/ ijms 17040506 .

2. Anderson ME. Update on Survival in Osteosarcoma. Orthop Clin North Am. 2016; 47(1): 283-92. 
3. Longhi A, Ferrari S, Bacci G, Specchia S. Long-Term FollowUp of Patients with Doxorubicin-Induced Cardiac Toxicity after Chemotherapy for Osteosarcoma. Anticancer Drugs. 2007; 18(6): 737-44.

4. Zhou W, Hao M, Du X, Chen K, Wang G, Yang J. Advances in Targeted Therapy for Osteosarcoma. Discov Med. 2014; 17(96): 301-7.

5. Wu CC, Cheng CH, Lee YH, Chang IL, Chen HY, Hsieh CP, et al. Ursolic Acid Triggers Apoptosis in Human Osteosarcoma Cells via Caspase Activation and the ERK1/2 MAPK Pathway. J Agric Food Chem. 2016; 64(21): 4220-6.

6. Wang T, Gong X, Jiang R, Li H, Du W, Kuang G. Ferulic Acid Inhibits Proliferation and Promotes Apoptosis via Blockage of PI3K/Akt Pathway in Osteosarcoma Cell. Am J Transl Res. 2016; 8(2): 96880.

7. Ge Y, Wang Y, Pang L, Zhang L, Zhai Y, Zhou H. Proliferation, Apoptosis and Invasion Effects of Mistletoe Alkali on Human Osteosarcoma U2OS In Vitro. Int Surg. 2016 Apr 25. [Epub ahead of print]

8. Sandra F. Kukita T, Tang QY, Iijima T. Cafeic Acid Inhibits Nfkb Activation of Osteoclastogenesis Signaling Pathway. Indones Biomed J. 2011; 3(3): 216-22.

9. Tang QY, Kukita T, Ushijima Y, Kukita A, Nagata K, Sandra F, et al. Regulation of Osteoclastogenesis by Simon Extracts Composed of Caffeic Acid and Related Compounds: Successful Suppression of Bone Destruction Accompanied with Adjuvant-Induced Arthritis in Rats. Histochem Cell Biol. 2006; 125(3): 215-25.

10. Sandra F, Kukita T, Muta T, Iijima T. Caffeic Acid Inhibited Receptor Activator of Nuclear Factor $\mathrm{kB}$ Ligand (RANKL)-Tumor Necrosis Factor (TNF) $\alpha$-TNF Receptor Associated Factor (TRAF) 6 Induced Osteoclastogenesis Pathway. Indones Biomed J. 2013; 5(3): 173-8.

11. Chang HT, Chen IL, Chou CT, Liang WZ, Kuo DH, Shieh P, et al. Effect of Caffeic Acid on $\mathrm{Ca}(2+)$ Homeostasis and Apoptosis in SCM1 Human Gastric Cancer Cells. Arch Toxicol. 2013; 87(12): 2141-50

12. Chang WC, Hsieh CH, Hsiao MW, Lin WC, Hung YC, Ye JC. Caffeic Acid Induces Apoptosis in Human Cervical Cancer Cells Through the Mitochondrial Pathway. Taiwan J Obstet Gynecol. 2010; 49: 419-24.
13. Krzyzankova M, Chovanova S, Chlapek P, Radsetoulal M, Neradil J, Zitterbart K, et al. LOX/COX Inhibitors Enhance the Antineoplastic Effects of All-Trans Retinoic Acid in Osteosarcoma Cell Lines. Tumour Biol. 2014; 35(8): 7617-27.

14. Sandra F, Khosravi-Far R. Survivin S81A Enhanced TRAIL's Activity in Inducing Apoptosis. Indones Biomed J. 2010; 2(3): 113-7.

15. Sandra F, Sudiono J, Sidharta EA, Sunata EP, Sungkono DJ, Dirgantara $\mathrm{Y}$, et al. Conditioned Media of Human Umbilical Cord Blood Mesenchymal Stem Cell-Derived Secretome Induced Apoptosis and Inhibited Growth of HeLa Cells. Indones Biomed J. 2014; 6(1): 57-62.

16. Sandra F, Hendarmin L, Kukita T, Nakao Y, Nakamura N, Nakamura S. Ameloblastoma Induces Osteoclastogenesis: a Possible Role of Ameloblastoma in Expanding in the Bone. Oral Oncol. 2005; 41(6): 637-44.

17. Tang $\mathrm{CH}$, Chuang JY, Fong YC, Maa MC, Way TD, Hung CH. BoneDerived SDF-1 Stimulates IL-6 Release via CXCR4, ERK and NFkappaB Pathways and Promotes Osteoclastogenesis in Human Oral cancer cells. Carcinogenesis. 2008; 29(8): 1483-92.

18. Costa-Rodrigues J, Teixeira CA, Fernandes MH. Paracrine-Mediated Osteoclastogenesis by the Osteosarcoma MG63 Cell Line: is RANKL/RANK Signalling Really Important?. Clin Exp Metastasis. 2011; 28(6): 505-14.

19. Taylor R, Knowles HJ, Athanasou NA. Ewing Sarcoma Cells Express RANKL and Support Osteoclastogenesis. J Pathol. 2011; 225(2): 195-202.

20. Fischer U, Jänicke RU, Schulze-Osthoff K. Many Cuts to Ruin: a Comprehensive Update of Caspase Substrates. Cell Death Differ. 2003; 10(1): 76-100.

21. Reyland ME. Protein Kinase Cdelta and Apoptosis. Biochem Soc Trans. 2007; 35(5): 1001-4.

22. Sandra F, Hendarmin L, Nakao Y, Nakamura N, Nakamura S. TRAIL Cleaves Caspase- $8,-9$ and -3 of AM-1 Cells: a Possible Pathway for TRAIL to Induce Apoptosis in Ameloblastoma. Tumour Biol. 2005; 26(5): 258-64.

23. Sandra F, Degli Esposti M, Ndebele K, Gona P, Knight D, Rosenquist $\mathrm{M}$, et al. Tumor Necrosis Factor-Related Apoptosis-Inducing Ligand Alters Mitochondrial Membrane Lipids. Cancer Res. 2005; 65(18): 8286-97. 